\title{
Association between Gender and Anxiety among Covid-19 Patients: A Meta-Analysis
}

\author{
Zuraida Zulkarnain'), Arum Nuryati2), Desif Upix3), Danang Ardiyanto'), Adilla Misi4), \\ Andi Siswanto5), Atik Handariati6), Alfiana Nur Rohmani4), Saryanto'), Zadia Dara') \\ 1)Research and Development Center of Traditional Medicinal \\ and Medicinal Plants, Karanganyar, Central Java \\ 2)School of Health Sciences Guna Darma, Yogyakarta \\ 3)Community Health Center Gamping, Yogyakarta \\ 4) Health Polytechnics, Ministry of Health Surakarta, Central Java \\ 5) Regency Health Office of Karanganyar, Central Java \\ 6)Academy of Physiotherapy, Dustira Hospital, Bandung, West Java \\ 7)Universitas Respati Yogyakarta
}

\section{ABSTRACT}

Background: The COVID-19 outbreak rapidly spread worldwide, with a significant number of cases and deaths causing anxiety, especially among the sufferers. Biologically, males and females show different psychological responses to the events at hand. This study aimed to examine the association between gender and anxiety among COVID-19 patients.

Subjects and Method: This study was a meta-analysis. The articles were obtained from databases PubMed and Scopus using keywords "Anxiety" OR "anxiety disorder" AND "COVID19 Patients" OR "Patients with COVID-19" OR "Hospitalized" AND "Risk factors" OR "determinants" OR "Gender" OR "Factors associated". The articles included in this study were full-text with a cross-sectional design, discussed the association between gender and anxiety among COVID-19 patients, published in English, studies located in Asia. The final results were presented in Adjust Odds Ratio (aOR) or Standardized Mean Difference (SMD). Data analysis was performed using Revman 5.3 software, with generic inverse variance data type for categorical outcome group (CtOG) articles and continuous data type for continue outcome group ( $\mathrm{CnOG}$ ).

Results: 9 articles were analyzed, including 4 articles CtOG and 5 articles CnOG. The forest plot of both categorical and continue outcomes showed consistent result that among COVID-19 patients who hospitalized with mild to severe symptoms. Female patients significantly had higher anxiety event $(\mathrm{aOR}=2.19 ; 95 \% \mathrm{CI}=1.60$ to $2.99 ; \mathrm{p}<0.001 ; \mathrm{I}^{2}=0 \%$ and $\mathrm{SMD}=0.35 ; 95 \%$ $\mathrm{CI}=0.21$ to $\left.0.49 ; \mathrm{p}<0.001 ; \mathrm{I}^{2}=12 \%\right)$.

Conclusion: Among COVID-19 patients, the female gender has a significantly higher risk of suffering from anxiety than the male gender.

Keywords: anxiety, COVID-19

\section{Correspondence:}

Zuraida Zulkarnain. Research and Development Center of Traditional Medicinal and Medicinal Plants, Karanganyar, Central Java. Mobile: o81393933862. e-mail: zuraida.zu@gmail.com.

\section{Cite this as:}

Zulkarnain Z, Nuryati A, Upix D, Ardiyanto D, Misi A, Siswanto A, Handariati A, Rohmani AN, Saryanto, Dara Z (2021). Association between Gender and Anxiety among Covid-19 Patients: A Meta-Analysis. J Health Policy Manage. 06(02): 94-106. https://doi.org/10.26911/thejhpm.2021.06.02.02.

(c) (i) (-) Journal of Health Policy and Management is licensed under a Creative Commons Attribution-NonCommercial-ShareAlike 4.o International License.

\section{BACKGROUND}

Corona Virus Disease (COVID-19) was first identified in Wuhan, China, in December 2019 as a disease caused by a new type of
Coronavirus, namely SARS-CoV-2 ( $\mathrm{Zu}$ et al., 2020). The virus causes acute and severe respiratory disorders (Severe Acute Respiratory Syndrome). The outbreak ra- 
pidly spread around the world, significantly increasing the incidence of cases and deaths. On January 30, 2020, WHO officially declared the SARS-CoV-2 outbreak a Public Health Emergency of International Concern (PHEIC) (WHO, 2020). The development of the COVID-19 case still attracts world attention, including the Incidence Rate (IR), Case Fatality Rate (CFR), and Recovery Rate. As of March 31, 2021, WHO recorded 127,906,158 cases of COVID-19 throughout the world, with CFR reaching $2.18 \%$ or $2,797,527$ cases of which died (WHO, 2021).

Recommendations for controlling and handling COVID-19 include limiting social mobilization and contact and implementing self-quarantine. This fosters stigma in society and affects the mental health of a person with a diagnosis of COVID-19. The 14-day quarantine period caused various reactions for each individual, ranging from boredom, anxiety, depression, loneliness, and emotional stablity. Changes in psychological conditions have long-term implications for individual productivity in the future.

Medical examinations are too focused on the patient's physical condition, so that the patient's psychological state is often neglected. This is exacerbated by the failure to control virus transmission, which can create clusters in the family. If examined further, psychological disorders in COVID19 patients have the risk of affecting a person's quality of life in the longer term. Studies of the psychological impact of COVID-19 patients have been carried out in several studies, both using observational and experimental/ intervention techniques. A study in Spain analyzed the presence of psychological disorders as a response to general outbreaks (Losada-Baltar et al., 2020). In addition, several studies had analyzed the existence of psychological dis- orders in medical personnel in several countries as a direct impact of psychological pressure on medical personnel is facing a pandemic situation ( $\mathrm{Lu}$ et al., 2020). Meanwhile, research in Bangladesh showed that $71 \%$ of study subjects experienceed mental health problems, such as depression, anxiety, and insomnia, during the COVID-19 pandemic (Das et al., 2021).

Biologically, males and females show different psychological responses to the events at hand. This is because females produce the hormones estrogen and progesterone, which affect brain performance. The prevalence of anxiety disorders in females is up to 2 times more at risk than in the male group. However, studies related to mental disorders during the COVID-19 pandemic in China showed quite different results. $48.15 \%$ of female respondents experience anxiety, and $51.85 \%$ of men experience anxiety (Xu et al., 2021). Handayani et al. (2020) also stated that factors causing stress to society include sex or gender. Therefore, this study focused on the relationship between gender and the anxiety level of COVID-19 patients using MetaAnalysis.

\section{SUBJECTS AND METHOD}

\section{Study Design}

This was a systematic study with the MetaAnalysis approach. This study used secondary data from the result of the previous studies. Articles were obtained from databases, namely PubMed and Scopus. The keywords used "Anxiety" OR "anxiety disorder" AND "COVID-19 Patients" OR "Patients with COVID -19" OR "Hospitalized" AND "Risk factors" OR "determinants" OR "Gender" OR "Factors associated".

\section{Inclusion Criteria}

The articles included in this study were fulltext with a cross-sectional design. The se- 
lected articles discussed the association between gender and anxiety among COVID19 patients. The articles were published in English. The study samples were patients who confirmed COVID-19 infection, in which studies were located in Asia. The data of study results were multivariate. The final result of the study was reported using Adjust Odds Ratio (aOR) for categorical data and Standardized Mean Difference (SMD) for continuous data.

\section{Exclusion Criteria}

The articles excluded in this study were the articles with RCT study design, case-control, quasi-experiment, and study protocol. The articles were not published in English. The statistical results were not reported aOR or SMD for the outcome variables.

\section{Operational Definition of Variables}

The article search was carried out by considering the eligibility criteria defined using the PICO model. The population of this study was COVID-19 patients. The comparison was gender, which consisted of female

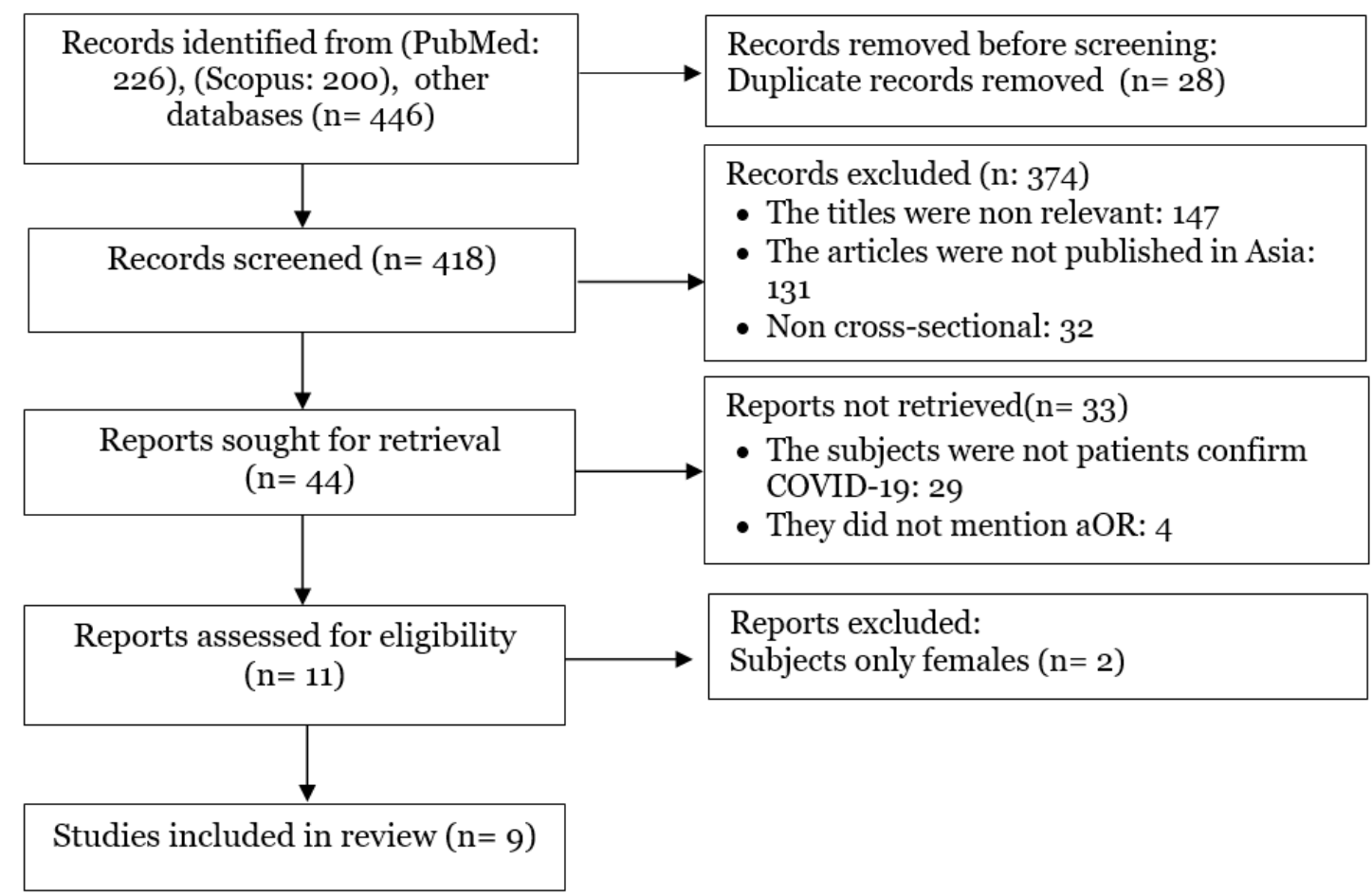

Figure 1. PRISMA Flow Diagram 
1. Association between gender and anxiety among COVID-19 patients with categorical data

a. Summary source

Table 1. The description of the primary studies included in the Meta-Analysis

\begin{tabular}{|c|c|c|c|c|c|c|}
\hline $\begin{array}{c}\text { Author } \\
\text { (Year) }\end{array}$ & Title & Country & $\begin{array}{c}\text { Study } \\
\text { Design }\end{array}$ & Population and Sample & $\begin{array}{c}\text { Intervention } \\
\text { and } \\
\text { Comparison }\end{array}$ & Outcome \\
\hline $\begin{array}{l}\text { Gu et al., } \\
2020\end{array}$ & $\begin{array}{l}\text { Factors associated with } \\
\text { mental health outcomes } \\
\text { among patients with } \\
\text { COVID-19 treated in the } \\
\text { Fangcang shelter hospital } \\
\text { in China }\end{array}$ & China & $\begin{array}{l}\text { Cross- } \\
\text { sectional }\end{array}$ & $\begin{array}{l}299 \text { female and } 162 \text { male } \\
\text { patients confirmed COVID-19 } \\
\text { with mild to the moderate } \\
\text { symptom, who were in care at } \\
\text { Fangcang shelter hospital } \\
\text { China }\end{array}$ & $\begin{array}{l}\text { I: Women } \\
\text { C: Men }\end{array}$ & $\begin{array}{l}50.1 \% \text { of participants } \\
\text { experience anxiety, } \\
\text { and the female } \\
\text { gender was } \\
\text { associated with } \\
\text { anxiety }\end{array}$ \\
\hline $\begin{array}{l}\text { Zhang et al., } \\
2020\end{array}$ & $\begin{array}{l}\text { The relationship between } \\
\text { resilience, anxiety, and } \\
\text { depression among patients } \\
\text { with mild symptoms of } \\
\text { COVID-19 in China: A } \\
\text { cross-sectional study }\end{array}$ & China & $\begin{array}{l}\text { Cross- } \\
\text { sectional }\end{array}$ & $\begin{array}{l}123 \text { female and } 173 \text { male } \\
\text { patients confirmed COVID-19 } \\
\text { with mild symptoms who were } \\
\text { in care at Fangcang hospital }\end{array}$ & $\begin{array}{l}\text { I: Women } \\
\text { C: Men }\end{array}$ & $\begin{array}{l}29,3 \% \text { female and } \\
15 \% \text { male } \\
\text { participants had } \\
\text { anxiety. }\end{array}$ \\
\hline $\begin{array}{l}\text { Kang et al., } \\
2021\end{array}$ & $\begin{array}{l}\text { The psychological burden } \\
\text { of COVID-19 stigma: } \\
\text { Evaluation of the mental } \\
\text { health of isolated mild } \\
\text { condition COVID-19 } \\
\text { patients }\end{array}$ & Korea & $\begin{array}{l}\text { Cross- } \\
\text { sectional }\end{array}$ & $\begin{array}{l}56 \text { female and } 51 \text { male patients } \\
\text { confirmed COVID-19 with mild } \\
\text { symptoms, who were in care at } \\
\text { Community Care Center (CTC) } \\
\text { Seoul National University } \\
\text { Hospital }\end{array}$ & $\begin{array}{l}\text { I: Women } \\
\text { C: Men }\end{array}$ & $\begin{array}{l}\text { The prevalence of } \\
\text { more than moderate } \\
\text { anxiety was } 14 \cdot 9 \% \text {. } \\
\text { There is no correla- } \\
\text { tion between gender } \\
\text { and anxiety. }\end{array}$ \\
\hline $\begin{array}{l}\text { Li et al., } \\
2020\end{array}$ & $\begin{array}{l}\text { The associated factors of } \\
\text { anxiety and depressive } \\
\text { symptoms in COVID-19 } \\
\text { patients hospitalized in } \\
\text { Wuhan, China }\end{array}$ & China & $\begin{array}{l}\text { Cross- } \\
\text { sectional }\end{array}$ & $\begin{array}{l}45 \text { female and } 54 \text { male patients } \\
\text { confirmed COVID -19 with } \\
\text { mild to moderate symptoms, } \\
\text { who were in care at epidemic } \\
\text { center Leishenshan Hospital }\end{array}$ & $\begin{array}{l}\text { I: Women } \\
\text { C: Men }\end{array}$ & $\begin{array}{l}\text { There was no signifi- } \\
\text { cant difference in } \\
\text { anxiety symptoms } \\
\text { between females and } \\
\text { males. About } 15.2 \% \\
\text { of participants had } \\
\text { abnormal anxiety } \\
\text { scores. }\end{array}$ \\
\hline
\end{tabular}


Zulkarnain et al./ Association between Gender and Anxiety among Covid-19 Patients

\section{b. Forest Plot}

Odds Ratio

Study or Subgroup log[Odds Ratio] SE Weight IV, Fixed, $95 \% \mathrm{Cl}$

\begin{tabular}{lrrrr}
\hline Gu et al, 2020 & 0.8587 & 0.2178 & $53.5 \%$ & $2.36[1.54,3.62]$ \\
Kang et al, 2021 & 0.3507 & 0.5751 & $7.7 \%$ & $1.42[0.46,4.38]$ \\
Li et al, 2020 & 0.6729 & 0.4572 & $12.1 \%$ & $1.96[0.80,4.80]$ \\
Zhang et al. 2020 & 0.8007 & 0.3083 & $26.7 \%$ & $2.23[1.22,4.08]$ \\
& & & \\
Total $(95 \%$ Cl) & $100.0 \%$ & $2.19[1.60,2.99]$ \\
Heterogeneity: Chi ${ }^{2}=0.75, \mathrm{df}=3(\mathrm{P}=0.86) ;\left.\right|^{2}=0 \%$ \\
Test for overall effect: $Z=4.91(\mathrm{P}<0.00001)$
\end{tabular}

\section{Figure 2. Forest plot}

In Figure 2, the Forest plot showed that female COVID-19 Patients had more risk 2.19 times than male COVID-19 patients to suffer anxiety $(\mathrm{aOR}=2.19 ; 95 \% \mathrm{CI}=1.60$ to

\section{c. Funnel Plot}

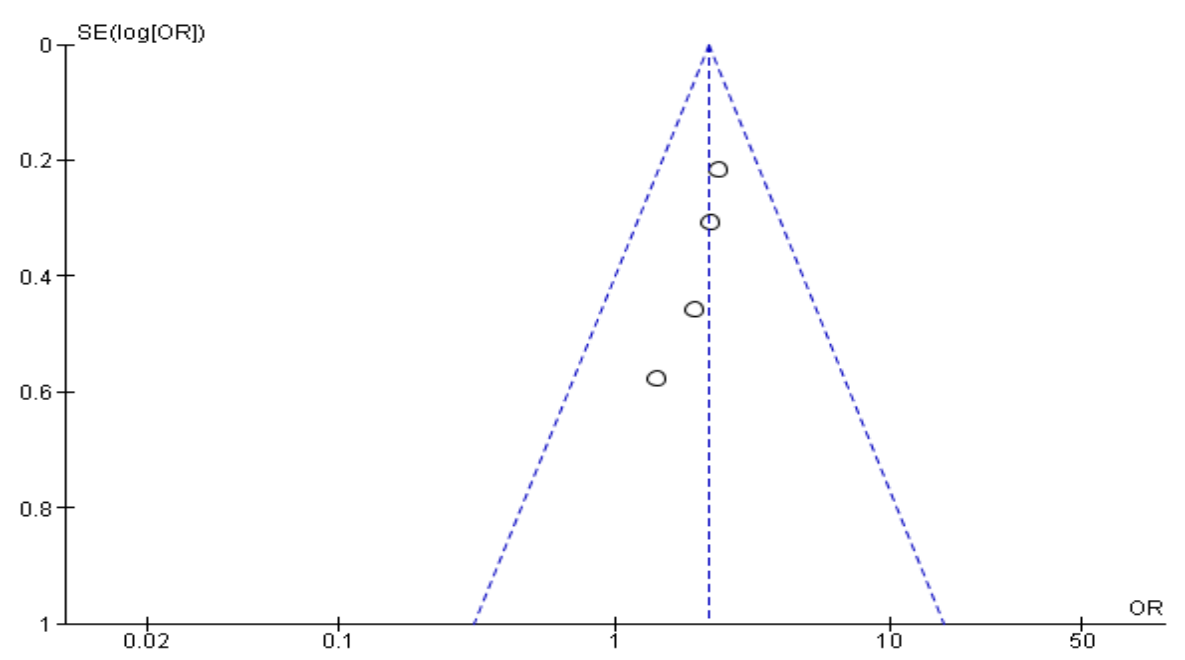

Figure 3. Funnel plot

In Figure 3, the funnel plot showed publication bias indicated the asymmetry of the right plot and left plot. The plot to the
2.99; $\left.\mathrm{p}<0.001 ; \mathrm{I}^{2}=0 \%\right)$. The distribution of the data was homogenous (fixed-effect model).
Odds Ratio

IV, Fixed, $95 \% \mathrm{Cl}$

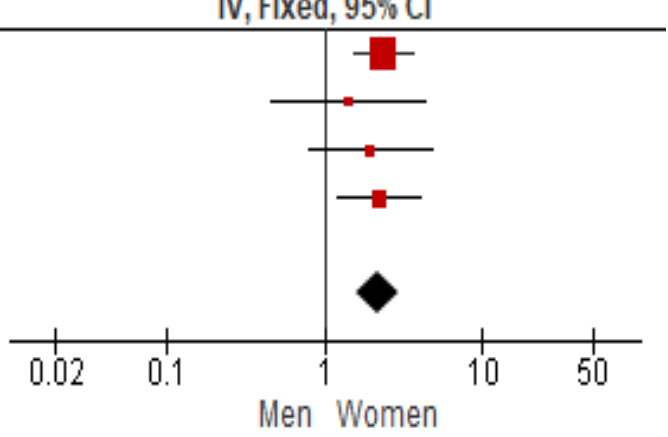


2. Association between gender and anxiety among COVID-19 patients with continuous data

a. Summary source

Table 1. The description of the primary study included in the Meta-Analysis

\begin{tabular}{|c|c|c|c|c|c|c|}
\hline $\begin{array}{l}\text { Author } \\
\text { (Year) }\end{array}$ & Title & Country & Study Design & Population and Sample & $\begin{array}{l}\text { Intervention } \\
\text { and } \\
\text { Comparison }\end{array}$ & Outcome \\
\hline $\begin{array}{l}\text { Nie et al., } \\
2020\end{array}$ & $\begin{array}{l}\text { Anxiety and depression } \\
\text { and its correlates in } \\
\text { patients with } \\
\text { coronavirus disease } \\
2019 \text { in Wuhan }\end{array}$ & China & Cross-sectional & $\begin{array}{l}45 \text { female and } 33 \text { male patients } \\
\text { confirmed COVID-19 with mild to } \\
\text { the severe symptom (based on } \\
\text { American Thoracic Society } \\
\text { Guidelines for community- } \\
\text { acquired pneumonia Hospitalized } \\
\text { at Wuhan No.1 hospital }\end{array}$ & $\begin{array}{l}\text { I: Women } \\
\text { C: Men }\end{array}$ & $\begin{array}{l}\text { Anxiety symptoms were diagnosed } \\
\text { in } 38.5 \% \text { of patients. Using } \\
\text { multivariate regression linear } \\
\text { analysis, there was no significant } \\
\text { correlation between gender and } \\
\text { anxiety, although the average } \\
\text { anxiety score was higher in female } \\
\text { than male patients }\end{array}$ \\
\hline $\begin{array}{l}\text { Sahan et } \\
\text { al. } 2020\end{array}$ & $\begin{array}{l}\text { Can we predict who will } \\
\text { be more anxious and } \\
\text { depressed in the COVID- } \\
19 \text { ward? }\end{array}$ & Turkey & Cross-sectional & $\begin{array}{l}138 \text { female and } 143 \text { male patients } \\
\text { confirmed COVID-19 who } \\
\text { hospitalized in Bezmialem Vakif } \\
\text { University Hospital }\end{array}$ & $\begin{array}{l}\text { I: Women } \\
\text { C: Men }\end{array}$ & $\begin{array}{l}34.9 \% \text { of patients had a significant } \\
\text { level of anxiety. Female gender was } \\
\text { associated with symptoms of anxiety }\end{array}$ \\
\hline $\begin{array}{l}\text { Kong et } \\
\text { al., } 2020\end{array}$ & $\begin{array}{l}\text { Effect of psychological- } \\
\text { behavioral intervention } \\
\text { on the depression and } \\
\text { anxiety of COVID-19 } \\
\text { patients }\end{array}$ & China & $\begin{array}{l}\text { RCT that } \\
\text { included the } \\
\text { analysis of fac- } \\
\text { tors associated } \\
\text { with anxiety } \\
\text { disorder }\end{array}$ & $\begin{array}{l}74 \text { female and } 70 \text { male patients } \\
\text { confirmed COVID-19 hospitalized } \\
\text { at Huoshenshan Hospital }\end{array}$ & $\begin{array}{l}\text { I: Women } \\
\text { C: Men }\end{array}$ & $\begin{array}{l}34.72 \% \text { of patients had symptoms of } \\
\text { anxiety. Female gender was } \\
\text { associated with anxiety symptoms }\end{array}$ \\
\hline $\begin{array}{l}\text { Jiang et } \\
\text { al., } 2021\end{array}$ & $\begin{array}{l}\text { Psychological distress } \\
\text { and sleep quality of } \\
\text { COVID-19 patients in } \\
\text { Wuhan, a lockdown city } \\
\text { as the epicenter of } \\
\text { COVID-19 }\end{array}$ & China & Cross-sectional & $\begin{array}{l}45 \text { female and } 55 \text { male patients } \\
\text { confirmed COVID-19 hospitalized } \\
\text { at Leishenshan Hospital with fever } \\
\text { and respiratory symptoms. } \\
\text { Computed Tomography (CT) scan } \\
\text { of the chest showed viral } \\
\text { pneumonia }\end{array}$ & $\begin{array}{l}\text { I: Women } \\
\text { C: Men }\end{array}$ & $\begin{array}{l}15.2 \% \text { of patients experience } \\
\text { anxiety. There was no significant } \\
\text { correlation between gender and } \\
\text { anxiety }\end{array}$ \\
\hline $\begin{array}{l}\text { Moayed } \\
\text { et al, } \\
2021\end{array}$ & $\begin{array}{l}\text { Depression, anxiety, } \\
\text { and stress among } \\
\text { patients with COVID-19: } \\
\text { A cross-sectional study }\end{array}$ & Iran & Cross-sectional & $\begin{array}{l}17 \text { female and } 204 \text { male patients } \\
\text { confirmed COVID-19 hospitalized } \\
\text { at Baqiyatallah hospital and other } \\
\text { hospitals who gave consent to } \\
\text { participate in this study }\end{array}$ & $\begin{array}{l}\text { I: Women } \\
\text { C: Men }\end{array}$ & $\begin{array}{l}\text { The prevalence of extremely severe } \\
\text { symptoms of anxiety was } 97.29 \% \text {. }\end{array}$ \\
\hline
\end{tabular}


Zulkarnain et al./ Association between Gender and Anxiety among Covid-19 Patients

a. Forest Plot

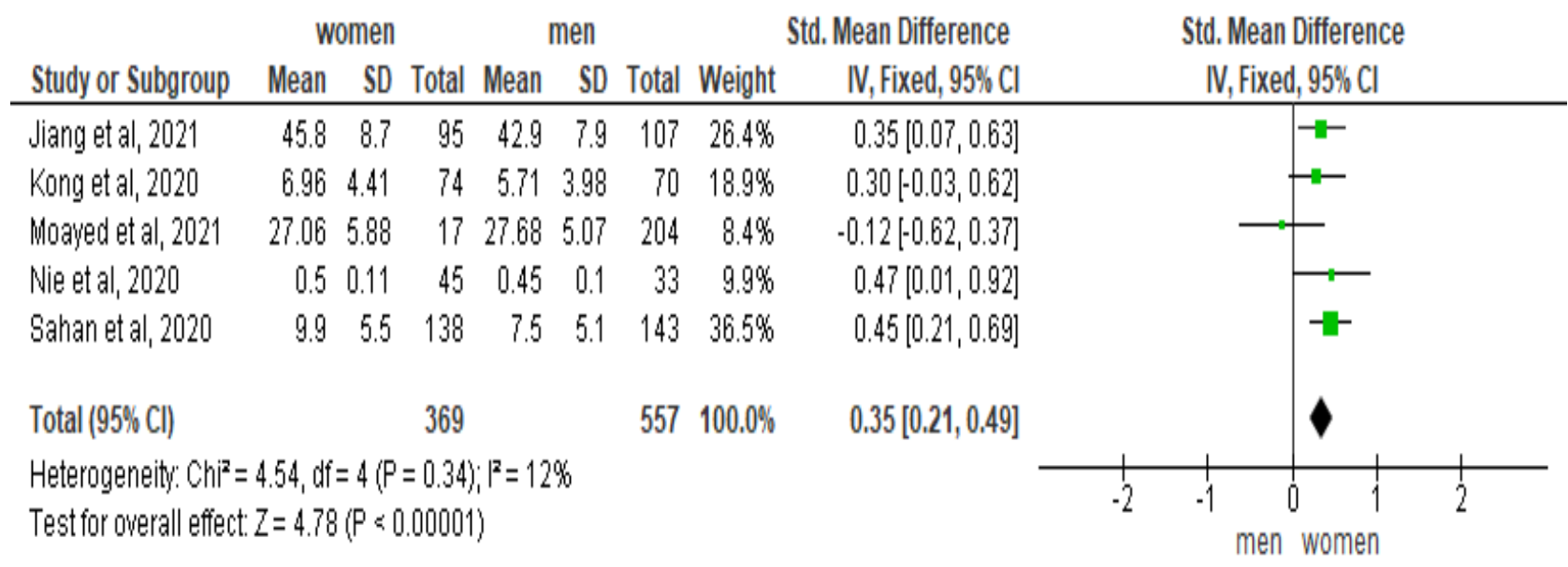

Figure 4. Forest plot

The Forest plot in Figure 4 showed Metaanalysis for continuous data that COVID-19 female patients had a probability of suffering anxiety 0.35 times than male $(\mathrm{OR}=0.35 ; 95 \% \mathrm{CI}=0.21$ to $0.49 ; \mathrm{p}<0.001$; $\left.\mathrm{I}^{2}=12 \%\right)$. The distribution of the data was homogenous (fixed-effect model).
In Figure 5, the funnel plot showed asymmetric from the right plot and left plot. In addition, the distance between the left plot and the centerline was farther than the distance between the right plot and the centerline.

\section{b. Funnel Plot}

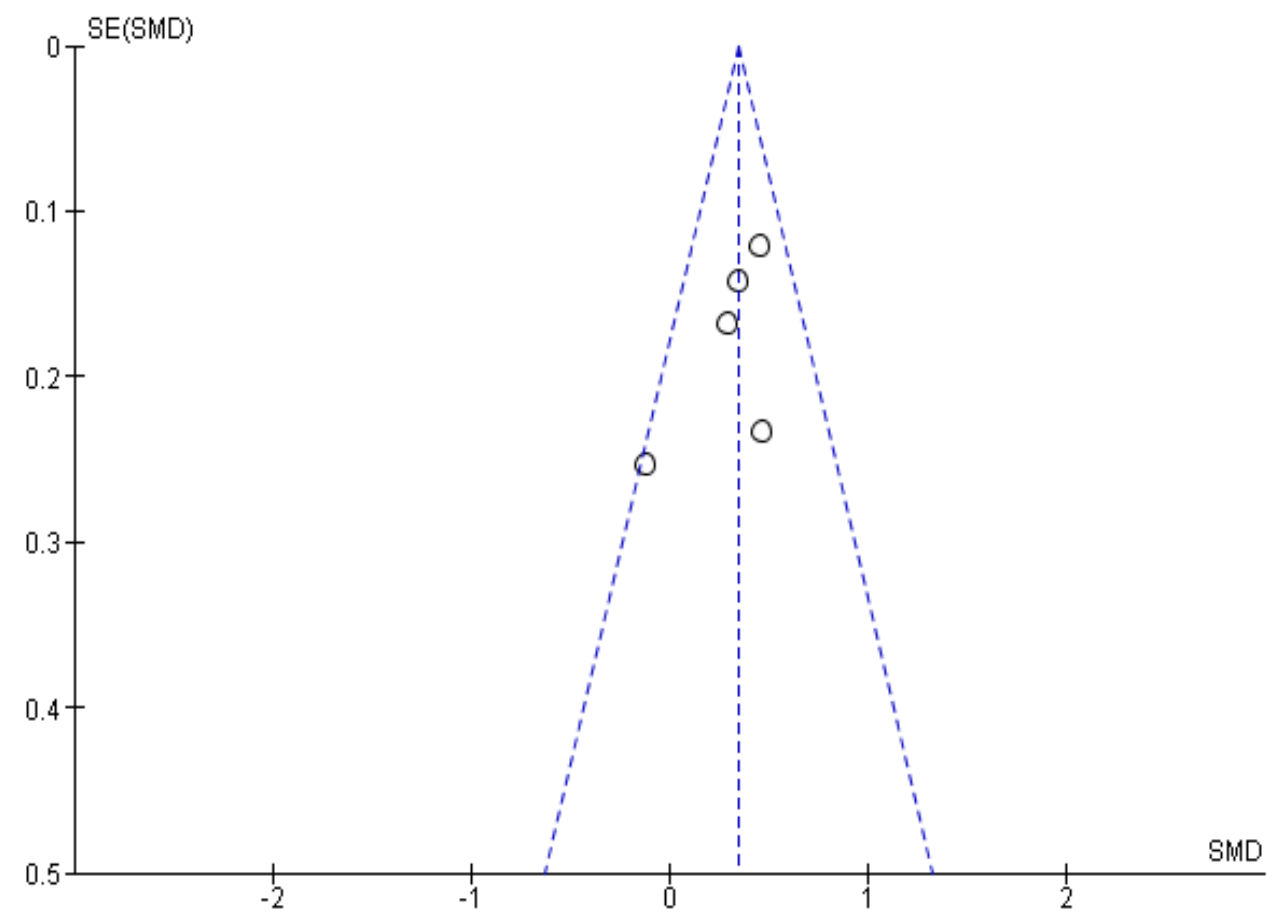

Figure 5. Funnel plot 
3. The assessment of study quality of gender-associated anxiety among COVID-19 patients

\begin{tabular}{|c|c|c|c|c|c|c|c|c|c|c|c|c|c|}
\hline \multirow{2}{*}{$\begin{array}{l}\text { Primary } \\
\text { Study }\end{array}$} & \multirow{2}{*}{ Title } & \multicolumn{12}{|c|}{ Questions ( $Y=$ Yes, $N=$ No, $C=$ Can't tell) } \\
\hline & & $\mathbf{1}$ & 2 & 3 & 4 & 5 & 6 & 7 & 8 & 9 & $\mathbf{1 0}$ & $\mathbf{1 1}$ & 12 \\
\hline $\begin{array}{l}\text { Gu et al., } \\
2020\end{array}$ & $\begin{array}{l}\text { Factors associated with mental health outcomes among } \\
\text { patients with COVID-19 treated in the Fangcang shelter } \\
\text { hospital in China }\end{array}$ & $\mathrm{Y}$ & $\mathrm{Y}$ & $\mathrm{Y}$ & $\mathrm{Y}$ & $\mathrm{Y}$ & $\mathrm{N}$ & $\mathrm{Y}$ & $\mathrm{Y}$ & $\mathrm{Y}$ & $\mathrm{Y}$ & $\mathrm{Y}$ & $\mathrm{Y}$ \\
\hline $\begin{array}{l}\text { Zhang et al. } \\
2020\end{array}$ & $\begin{array}{l}\text { The relationship between resilience, anxiety, and depression } \\
\text { among patients with mild symptoms of COVID-19 in China: } \\
\text { A cross-sectional study }\end{array}$ & $\mathrm{Y}$ & $\mathrm{Y}$ & $\mathrm{Y}$ & $\mathrm{Y}$ & $\mathrm{Y}$ & $\mathrm{N}$ & $\mathrm{Y}$ & $\mathrm{Y}$ & $\mathrm{Y}$ & $\mathrm{Y}$ & $\mathrm{Y}$ & $\mathrm{Y}$ \\
\hline $\begin{array}{l}\text { Kang et al., } \\
2021\end{array}$ & $\begin{array}{l}\text { The Psychological Burden of COVID-19 Stigma: Evaluation } \\
\text { of the Mental Health of Isolated Mild Condition COVID-19 } \\
\text { Patients }\end{array}$ & $\mathrm{Y}$ & $\mathrm{Y}$ & $\mathrm{Y}$ & $\mathrm{Y}$ & $\mathrm{Y}$ & $\mathrm{N}$ & $\mathrm{Y}$ & $\mathrm{Y}$ & $\mathrm{N}$ & $\mathrm{Y}$ & $\mathrm{Y}$ & $\mathrm{Y}$ \\
\hline $\begin{array}{l}\text { Li et al., } \\
2020\end{array}$ & $\begin{array}{l}\text { The associated factors of anxiety and depressive symptoms } \\
\text { in COVID-19 patients hospitalized in Wuhan, China }\end{array}$ & $\mathrm{Y}$ & $\mathrm{Y}$ & $\mathrm{Y}$ & $\mathrm{Y}$ & $\mathrm{Y}$ & $\mathrm{Y}$ & $\mathrm{N}$ & $\mathrm{Y}$ & $\mathrm{Y}$ & $\mathrm{Y}$ & $\mathrm{Y}$ & $\mathrm{Y}$ \\
\hline $\begin{array}{l}\text { Nie et al., } \\
2020\end{array}$ & $\begin{array}{l}\text { Anxiety and depression and its correlates in patients with } \\
\text { coronavirus disease } 2019 \text { in Wuhan }\end{array}$ & $\mathrm{Y}$ & $\mathrm{Y}$ & $\mathrm{Y}$ & $\mathrm{Y}$ & $\mathrm{Y}$ & $\mathrm{N}$ & $\mathrm{Y}$ & $\mathrm{Y}$ & $\mathrm{Y}$ & $\mathrm{Y}$ & $\mathrm{N}$ & $\mathrm{Y}$ \\
\hline $\begin{array}{l}\text { Sahan et al. } \\
2020\end{array}$ & $\begin{array}{l}\text { Can we predict who will be more anxious and depressed in } \\
\text { the COVID-19 ward? }\end{array}$ & $\mathrm{Y}$ & $\mathrm{Y}$ & $\mathrm{Y}$ & $\mathrm{N}$ & $\mathrm{Y}$ & $\mathrm{N}$ & $\mathrm{N}$ & $\mathrm{Y}$ & $\mathrm{Y}$ & $\mathrm{Y}$ & $\mathrm{Y}$ & $\mathrm{Y}$ \\
\hline $\begin{array}{l}\text { Kong et al., } \\
2020\end{array}$ & $\begin{array}{l}\text { Effect of psychological-behavioral intervention on the } \\
\text { depression and anxiety of COVID-19 patients }\end{array}$ & $\mathrm{Y}$ & $\mathrm{Y}$ & $\mathrm{Y}$ & $\mathrm{N}$ & $\mathrm{Y}$ & $\mathrm{Y}$ & $\mathrm{Y}$ & $\mathrm{Y}$ & $\mathrm{Y}$ & $\mathrm{Y}$ & $\mathrm{Y}$ & $\mathrm{Y}$ \\
\hline $\begin{array}{l}\text { Jiang et al., } \\
2021\end{array}$ & $\begin{array}{l}\text { Psychological distress and sleep quality of COVID-19 } \\
\text { patients in Wuhan, a lockdown city as the epicenter of } \\
\text { COVID-19 }\end{array}$ & $\mathrm{N}$ & $\mathrm{N}$ & $\mathrm{Y}$ & $\mathrm{Y}$ & $\mathrm{Y}$ & $\mathrm{Y}$ & $\mathrm{N}$ & $\mathrm{Y}$ & $\mathrm{N}$ & $\mathrm{Y}$ & $\mathrm{N}$ & $\mathrm{Y}$ \\
\hline $\begin{array}{l}\text { Moayed et } \\
\text { al., } 2021\end{array}$ & $\begin{array}{l}\text { Depression, anxiety, and stress among patients } \\
\text { with COVID-19: A cross-sectional study }\end{array}$ & $\mathrm{Y}$ & $\mathrm{Y}$ & $\mathrm{Y}$ & $\mathrm{N}$ & $\mathrm{N}$ & $\mathrm{Y}$ & $\mathrm{Y}$ & $\mathrm{Y}$ & $\mathrm{Y}$ & $\mathrm{Y}$ & $\mathrm{N}$ & $\mathrm{N}$ \\
\hline
\end{tabular}

Appraisal questions:

1. Did the study address a clearly focused question/issue?

2. Is the research method (study design) appropriate for answering the research question?

6. Was the sample size based on pre-study considerations of statistical power?

7. Was a satisfactory response rate achieved?

8. Are the measurements (questionnaires) likely to be valid and reliable?

Is the selection method (employees, teams, divisions, organizations) clearly described?

9. Was the statistical significance assessed?

10. Are confidence intervals given for the main results?

. Could the way the sample was obtained introduce (selection) bias?

5. Was the sample of subjects representative concerning the population to which the findings will be referred?

11. Could there be confounding factors that haven't been accounted for?

12. Can the results be applied to your organization?

(Center for Evidence-Based Management, 2014). 


\section{DISCUSSION}

This systematic and meta-analysis study proposed the theme of the anxiety symptoms on the patient with COVID-19 diseases. The dependent variable was anxiety symptoms. The study that discussed anxiety symptoms on COVID-19 patients was important because only several relevant studies were published, and it had data access problems.

The results of the Meta-Analysis were in the form of a forest plot and a funnel plot. The forest plot visually showed the variation in heterogeneity (Akobeng, 2005 in Murti, 2018). The funnel plot showed the relationship between the study's effect size and the sample size of the various studies examined, which could be measured in many different ways. There were 9 articles as a source of a Meta-Analysis of the anxiety symptoms on COVID-19 patients, four articles with categorical data outcome, and five articles with continuous data outcome. The forest plot in categorical outcome group showed that among COVID-19 patients, females 2.19 times more likely to experience anxiety symptoms than men, and it was statistically significant $(\mathrm{aOR}=$ $2.19 ; 95 \% \mathrm{CI}=1.60$ to $2.99 ; \mathrm{p}<0.001 ; \mathrm{I}^{2}=$ $0 \%)$. The forest plot result of the continuous data outcome group supported this finding showed that female COVID-19 patients had 0.35 times likely to suffer anxiety than male patients $(\mathrm{SMD}=0.35$; $95 \% \mathrm{CI}=0.21$ to $\left.0.49 ; \mathrm{p}<0.001 ; \mathrm{I}^{2}=12 \%\right)$.

\section{Comparison with previous epidemio-} logical data

There was data in previous studies that the overall prevalence of anxiety disorders worldwide was estimated to be normal, around $7.3 \%$ (95\% $\mathrm{CI}=4.8 \%$ to $10.9 \%$ ) (Stein et al., 2017). Signs of anxiety symptoms reported in the general population during previous epidemic outbreaks (Severe Acute Respiratory Syndrome, SARS;
$\mathrm{H} 1 \mathrm{~N} 1$, Ebola influenza) ranged between $3.2 \%$ and $12.6 \%$, which showed lower anxiety rates than during COVID-19 (Chew et al., 2020).

This could be possible because there were epidemics in the past with a higher mortality rate. Still, a lower rate of infection such as $\mathrm{H} 1 \mathrm{~N} 1$ influenza in 2009-2010 or epidemic conditions such as Ebola in 20142016 was resolved faster (Huremovi'c, 2019). The length of the COVID-19 pandemic is quite long, and different government policies around the world could be contributing to higher levels of anxiety during COVID-19, according to the negative psychological effects of quarantine were reported during the SARS outbreak in Toronto, Canada (Hawryluck et al., 2004). Previous research on Meta-Analysis at Salari et al. (2020), assessing the prevalence of the general anxiety population during the COVID-19 pandemic, included 17 studies, found a higher level of anxiety $31.9 \%$ (95\% CI= 27.5 to 36.7 ). In this study, the range of anxiety was between $14.9 \%$ in Korea and 97.29\% in Iran.

\section{Association between anxiety levels and Sex in COVID-19 patients}

Most studies showed significantly higher anxiety levels in women COVID-19 patients (Gu et al., 2020; Zhang et al., 2020; Kang et al., 2021; Li et al., 2020; Nie et al., 2020; Sahan et al., 2020; Kong et al., 2020; Jiang et al., 2021; Moayed et al., 2021). This was consistent with previous epidemiological data (Bandelow and Michaelis, 2015).

Several reasons could support more COVID-19 female patients who experienced symptoms of anxiety than men. First, women are known to use their feelings more when they are involved in a situation, especially when they encounter an illness (Fu et al., 2020). Second, it is known that there are differences in brain chemistry and hormones between men and women, which 
have been concluded to mediate the level of anxiety that is easier for a woman (Fu et al., 2020; Stanikova et al., 2019).

Third, women are known as the main caretakers of a family. Their role in the family can make them more vulnerable and an increased stressor to increase the burden at home after the policy of closing schools and other facilities (Rodríguez-Rey et al., 2020). Several studies stated that women show a stronger sense of loss of family ties during quarantine or while being hospitalized, which is associated with a greater perception of their daily activities being altered (Orellana and Orellana, 2020). Studies in Bangladesh showed that housewives experienced the most significant level of anxiety (Al Banna et al., 2020; Islam et al., 2020).

In other publications, women showed a higher incidence of stress than men (Stanton et al., 2020). When the quarantine period, women feel their ability to work in households is reduced, reducing the level of stability to the family's economy (Rodríguez-Rey et al., 2020). It can also be explained in a study that women showed a higher sense of concern about the effects of the pandemic COVID-19 on their economic status (Horesh et al., 2020).

Fourth, anxiety symptoms can be mediated by the increasing psychological impact of COVID-19 (Paulino et al., 2020). This could be due to the constant fear of COVID-19 transmission to their family or close friends (Horesh et al., 2020). Finally, many studies concluded that women were also at a higher risk of developing depression during the pandemic (Salari et al., 2020) and also a risk factor for anxiety (Jacobson and Newman, 2017).

The limitations of this study were that we included 2 articles with less than 100 subjects from Nie et al. (2020) and Lie et al. (2020), with the total number of subjects respectively 88 and 99 patients COVID-19 which contributed to publication bias. Six studies had unclear sampling techniques that could potentially lead to selection bias. In addition, different tools for assessing anxiety symptoms also increase the risk of bias. All primary studies in this meta-analysis used a questionnaire to assess symptoms of anxiety. There are differences in the questionnaire used, four studies using the Hospital Anxiety and Depression Scale (HADS), two studies using generalized anxiety disorder-7 (GAD-7), two studies using the Zung Self Rating Anxiety Scale (SAS), and one study using Depression Anxiety Stress Scale (DASS). All the tools used above have been tested for validity and reliability before being used. The strength of this study was the first meta-analysis linking gender to anxiety in COVID-19 patients.

Untreated anxiety can be prolonged and lead to a decrease in the quality of life of the sufferer. Based on Kong's 2010 study, the application of psychological behavior intervention for 10 days to COVID-19 patients who were hospitalized can significantly reduce anxiety scores. This intervention included breathing exercises and psychological support. In Indonesia, psychological counseling for COVID-19 patients has not become a government program. These findings can be an initial recommendation to include psychological counseling as one of the additional therapy for COVID-19 patients, especially females. Further research is still needed, given the limited data on anxiety in COVID-19 patients in Indonesia.

\section{AUTHOR CONTRIBUTION}

All authors had a role in selecting topics, tracking, collecting data, reviewing study documents, and analyzing data. 
Zulkarnain et al./ Association between Gender and Anxiety among Covid-19 Patients

CONFLICT OF INTEREST

There were no conflicts of interest.

\section{FUNDING AND SPONSORSHIP}

None.

\section{ACKNOWLEDGEMENT}

We would like to thank to open access journal databases that provide articles.

\section{REFERENCE}

Al Banna MH, Sayeed A, Kundu S, Christopher E, Hasan MT, Begum MR, Kormoker T, et al. (2020). The impact of the COVID-19 pandemic on the mental health of the adult population in Bangladesh: a nationwide crosssectional study. Int J Environ Health Res. 1-12. https://doi.org/10.1080/09603123.2020 .1802409$.

Bandelow B, Michaelis S (2015). Epidemiology of anxiety disorders in the 21st century. Dialogues Clin Neurosci. 17: 327-335. https://doi.org/10.1016/j.siny.2015.10.004.

Center for Evidence Based Management (2014). Critical Appraisal Checklist for Cross-Sectional Study. Available at: https://cebma.org/wp-content/uploads/Critical-Appraisal-Questions-for-a-Cross-Sectional-Study-July2014-1.pdf.

Chew NWS, Lee GKH, TanBYQ, Jing M, Goh Y, Ngiam NJH, Yeo LLL et al. (2020). A multinational, multicentre study on the psychological outcomes and associated physical symptoms amongst healthcare workers during COVID-19 outbreak. Brain Behav Immun. 1. https://doi.org/10.1016/j.bbi.2020.04.049.

Das R, Hasan MR, Daria S, Islam MR (2021). Impact of COVID-19 pandemic on mental health among general Bangladeshi population: a cross-sec- tional study. BMJ Open. 11: e045727. doi: 10.1136/bmjopen-2020-045727

Fu W, Wang C, Zou L, Guo Y, Lu Z, Yan S, Mao J (2020). Psychological health, sleep quality, and coping styles to stress facing the COVID-19 in Wuhan, China. Transl. Psychiatry. 10, 225. https://doi.org/10.1038/s41398-020oo913-3.

Gu Y, Zhu Y, Xu F, Xi J, Xu G (2021). Factors associated with mental health outcomes among patients with COVID-19 treated in the Fangcang shelter hospital in China. Asia-Pacific psychiatry: official journal of the Pacific Rim College of Psychiatrists. 13(2). e12443. https://doi.org/10.1111/appy.12443.

Handayani R, Kuntari S, Darmayanti A, Widiyanto A, Atmojo J (2020). Faktor penyebab stres pada tenaga kesehatan dan masyarakat saat pandemi Covid19. Jurnal Keperawatan Jiwa. 8 (3): 353-360. e-ISSN 2655-8106. https://jurnal.unimus.ac.id/index.php/JKJ/a rticle/view/5990.

Hawryluck L, Gold WL, Robinson S, Pogorski S, GaleaS, Styra R (2004). SARS control and psychological effects of quarantine, Toronto, Canada. Emerg Infect Dis. 10: 1206-1212. https://doi.org/10.3201/eid1007.030703.

Horesh D, Kapel Lev-AriR, Hasson-Ohayon I (2020). Risk factors for psychological distress during the COVID-19 pandemic in Israel: loneliness, age, gender, and health status play an important role. Br J Health Psychol. 1-9. https://doi.org/10.1111/ bjhp.12455.

Huremovi 'CD (2019). Mental health of quarantine and isolation. In: Psychiatry of Pandemics. Springer Nature Switzerland.

Islam MS, Ferdous MZ, Potenza MN 
Zulkarnain et al./ Association between Gender and Anxiety among Covid-19 Patients

(2020). Panic and generalized anxiety during the COVID-19 pandemic among Bangladeshi people: an online pilot survey early in the outbreak. $\mathrm{J}$ Affect Disord. 276: 30-37. https://doi.org/10.1016/j.

Jacobson NC, Newman MG (2017). Anxiety and depression as bidirectional risk factors for one another: a meta-analysis of longitudinal studies. Psychol. Bull. 143: 1155-1200. https://doi.org/10.1037/buloooo111.

Jiang Z, Zhu P, Wang L, Hu Y, Pang M, Ma $S$, Tang X (2021). Psychological distress and sleep quality of COVID-19 patients in Wuhan, a lockdown city as the epicenter of COVID-19. Journal of psychiatric research, 136: 595-602. https://doi.org/10.1016/j.jpsychires.2 020.10.034.

Kang E, Lee SY, Kim MS, Jung H, Kim KH, Kim KN, Park HY, et al. (2021). The psychological burden of COVID-19 stigma: Evaluation of the mental health of isolated mild condition COVID-19 Patients. J Korean Med Sci. 36(3). e33. https://doi.org/10.3346/jkms.2021.36.e33.

Kong X, KongF, ZhengK, Tang M, ChenY, Zhou J, Li Y, et al. (2020). Effect of psychological-behavioral intervention on the depression and anxiety of COVID-19 Patients. Frontiers in psychiatry, 11, 586355. https://doi.org/10.3389/fpsyt.2020.586355.

Li X, Tian J, Xu Q (2020). The associated factors of anxiety and depressive symptoms in COVID-19 patients hospitalized in Wuhan, China. Psychiatric Quarterly. Psychiatric Quarterly. doi: 10.1007/s11126-020-09865-9.

Losada-Baltar A, Jiménez-Gonzalo L, Gallego-Alberto L, Pedroso-Chaparro MDS, Fernandes-Pires J, Márquez-González M (2021). Association of self-percep- tions of aging, personal and family resources, and loneliness with psychological distress during the lock-down period of COVID-19. J Gerontol B Psychol Sci Soc Sci. 76(2):e10-e16. doi: 10.1093/geronb/gbaa048.

Lu H, Stratton CW, Tang YW (2020). Outbreak of pneumonia of unknown etiology in Wuhan, China: The mystery and the miracle. J Med Virol. 92(4): 401-402. doi: 10.1002/jmv.25678.

Moayed MS, Vahedian-Azimi A, Mirmomeni G, Rahimi-Bashar F, Goharimoghadam K, Pourhoseingholi MA, Abbasi-Farajzadeh M, et al. (2021). Depression, anxiety, and stress among patients with COVID-19: A cross-sectional study. Advances in experimental medicine and biology. 1321: 229236. https://doi.org/10.1007/978-3030-59261-5_19.

Nie XD, Wang Q, Wang MN, Zhao S, Liu L, Zhu YL, Chen H (2020). Anxiety and depression and its correlates in patients with coronavirus disease 2019 in Wuhan. Int J Psychiatry Clin Prac. 16. https://doi.org/10.1080/13651501.2020.1791345.

Orellana CI, Orellana LM (2020). Predictores de síntomas emocionales durante la cuarentena domiciliar por pandemia de COVID-19 en El Salvador. Actual. En Psicol. 34, 103-120. https://doi.org/10.15517/ap.v34i128.41431.

Paulino M, Dumas-Diniz R, Brissos S, Brites R, Alho L, Simo es MR, Silva CF (2020). COVID-19 in Portugal: exploring the immediate psychological impact on the general population. Psychol. Health Med. https://doi.org/10.1080/ 13548506.2020.1808236.

Rodríguez-Rey R, Garrido-Hernansaiz H, Collado S (2020). Psychological impact and associated factors during the initial stage of the coronavirus 
(COVID-19) pandemic among the general population in Spain. Front. Psychol. 11. https://doi.org/10.3389/ fpsyg.2020.01540.

Şahan E, Ünal SM Kırpınar İ (2021). 'Can we predict who will be more anxious and depressed in the COVID-19 ward?. J Psychosomatic Res. 140: 110302. doi: 10.1016/j.jpsychores.2020.110302.

Stein DJ, Scott KM, de Jonge P, Kessler RC (2017). Epidemiology of anxiety disorders: from surveys to nosology and back. Dialogues Clin Neurosci. 19(2): 127-136. https://dx.doi.org/10.31887\%2FDCNS.2017.19.2\%2Fdstein.

Salari N, Hosseinian-far A, Jalali R, Vaisiraygani A, Rasoulpoor S (2020). Prevalence of stress, anxiety, depression among the general population during the COVID-19 pandemic: a systematic review and meta-analysis. Glob Health. 16(1): 57. https://doi.org/10.1186/s12992-020-00589-w.

Stanikova D, Luck T, Pabst A, BaeYJ, Hinz

A, Glaesmer H, Stanik J (2019). Associations between anxiety, body mass index, and sex hormones in women. Frontiers in psychiatry, 10: 479. https://doi.org/10.3389/fpsyt.2019.0 0479.

StantonR, TomQG, Khalesi S, Williams SL, Alley SJ, Thwaite TL, Fenning AS et al. (2020). Depression, anxiety and stress during COVID-19: Associations with changes in physical activity, sleep, tobacco and alcohol use in Australian adults. Int $\mathrm{J}$ Environ Res Public Health, 17(11): 4065. https://doi.org/10.3390/ijerph17114065,

Xu Q, Mao Z, Wei D, Liu P, Fan K, Wang J, Wang X, et al. (2021). Prevalence and risk factors for anxiety symptoms during the outbreak of COVID-19: A large survey among 373216 junior and senior high school students in China. J Affect Disord. 288:17-22. doi: 10.1016/j.jad.2021.03.080.

Zhang J, Yang Z, Wang X, LiJ, Dong L, Wang F, Li Y et al. (2020). The relationship between resilience, anxiety and depression among patients with mild symptoms of COVID-19 in China: A cross-sectional study. J Clin Nursing, 29(21-22): 4020-4029. https://doi.org/10.1111/jocn.15425

Zu ZY, Jiang MD, Xu PP, Chen W, Ni QQ, Lu GM, Zhang LJ (2020). Coronavirus disease 2019 (COVID-19): A perspective from China. Radiology. 296 (2): E15-E25. https://doi.org/10.1148/radiol.2020200490. 